Research Article

\title{
A comparative study of antinociceptive effect of fluoxetine with pentazocine in rodent model
}

\author{
Manjunatha C. H. ${ }^{1}$, Jagadishchandra S. Ratnakar ${ }^{2}$
}

${ }^{1}$ Department of Pharmacology, Pondicherry Institute of Medical Sciences, Pondicherry, India ${ }^{2}$ Department of Pharmacology, Belgaum Institute of Medical Sciences, Belgaum, Karnataka, India

Received: 08 August 2016 Accepted: 10 September 2016

\section{*Correspondence to: Dr. Manjunatha C. H., Email: mnathakmc99@ gmail.com}

Copyright: (C) the author(s), publisher and licensee Medip Academy. This is an openaccess article distributed under the terms of the Creative Commons Attribution NonCommercial License, which permits unrestricted noncommercial use, distribution, and reproduction in any medium, provided the original work is properly cited.

\begin{abstract}
Background: Chronic pain affects millions of people across the globe, commonly coexisting with depression. Antidepressants like fluoxetine have shown potential to have analgesic activity with superior safety profile and hence might be better suited in the treatment of chronic pain. The objective of this study was to evaluate the antinociceptive activity of fluoxetine and to compare the antinociceptive effect of fluoxetine with pentazocine.

Methods: Adult albino rats weighing 150-200 grams were used in this study. Screening method used was Acetic acid induced writhing method in rats. Rats were divided into three groups of 5 animals and drugs administered as follows: group-1: distilled water (control), group-2: Fluoxetine, group-3: Pentazocine. All drugs were administered 30 minutes before the onset of pain stimulus. Statistical analysis was done by using one way-analysis of variance (one way ANOVA) followed by Tukey-Kramer test.

Results: Fluoxetine failed to show significant antinociceptive activity in Acetic acid induced writhing method.

Conclusions: Fluoxetine is an SSRI and one of the most commonly prescribed drug for depression. It is proven to act at multiple sites like serotonin transporter and opioid $\mu$ receptor, both of which may play a role in its analgesic activity.
\end{abstract}

Keywords: Analgesic effect, Fluoxetine, Acetic acid induced writhing method

\section{INTRODUCTION}

Pain is a subjective sensation hard to define exactly, even though we all know what we mean by it. Pain occurs whenever any tissues are being injured, and it causes the individual to react to remove the pain stimulus. It is the most common symptom that brings a patient to a doctors's attention.

Pain has been classified into two major types' fast pain and slow pain. Fast pain is also described by alternative names viz. sharp pain and acute pain. Slow pain is usually associated with tissue destruction. It can lead to prolonged, unbearable suffering. Chronic pain affects millions of people and commonly associated with depression. ${ }^{1}$ Currently the most commonly prescribed group of drugs for treatment of pain are non-steroidal anti-inflammatory drugs (NSAIDs) like Diclofenac and opioid analgesics. $^{2}$

Opioids are the most potent pain-relieving drugs currently available. Furthermore, of all analgesics, they have the broadest range of efficacy, providing the most reliable and effective method for rapid pain relief. But their use is limited by dose dependent side-effects like sedation, respiratory depression, pruritus, constipation and dependence liability (risk of addiction on long term use). 
Some of such conditions causing chronic pain include osteoarthritis, fibromyalgia and diabetic neuropathy. Because depression is the most common emotional disturbance in patients with chronic pain, patients should be questioned about their mood, appetite, sleep patterns, and daily activity. ${ }^{3}$

There are various other groups of drugs available for management of pain. These include antidepressants, anticonvulsants and antiarrhythmic.

Adjuvant analgesics like antidepressants have been made use in specific painful conditions like neuropathic pain due to diabetes mellitus. The selective serotonin reuptake inhibitors (SSRIs) such as fluoxetine have fewer and less serious side effects than TCAs, but they are much less effective in relieving pain. ${ }^{4}$

The previous studies conducted both on animals and humans to evaluate antinociceptive activity have conflicting results. Hence this present study was carried out with a view to elucidate analgesic activity of fluoxetine, an SSRI and to compare its activity with standard analgesic drug pentazocine.

The objective of this study was to evaluate the antinociceptive activity of fluoxetine and to compare the antinociceptive effect of fluoxetine with pentazocine.

\section{METHODS}

Adult albino rats (weighing: 150-200 gms), Acetic acid and Tuberculin syringe (for injection of drugs)

\section{Drugs}

Fluoxetine was obtained from Cipla, Mumbai and Pentazocine was obtained from Ranbaxy, Mumbai.

\section{Methodology}

The study was carried out at the Department of Pharmacology, M. R. Medical College, Gulbarga, on adult albino rats from central animal house of $\mathrm{M}$. R. Medical College after obtaining institution ethics committee approval to undertake this study.

Adult albino rats of either sex weighing about 150-200 grams were used for the study, maintained at a temperature of $25 \pm 1^{\circ} \mathrm{C}$ in a well-ventilated animal house and standard laboratory conditions of food and water before start of the experiment.

All drugs were administered 30 minutes before the onset of pain stimulus.

\section{Grouping of animals}

Analgesic activity was studied using rats in acetic acid induced writhing method observing the number of writhes. Rats were divided into three groups of 5 animals each $(n=5)$ as follows:

- Group 1: was given distilled water (control).

- Group 2: was given Fluoxetine (10 mg/kg i.p.)

- Group 3: was given Pentazocine (10 mg/kg i.p.)

\section{Care of the animals}

Handling and care of animals was according to committee for the purpose of control and supervision of experimental animals CPCSEA guidelines. Care during the animal study included food, water, shelter etc.

\section{Statistical methods}

The values obtained are expressed as mean \pm SEM. Statistical analysis of differences between groups was carried out using one-way analysis of variance (ANOVA) followed by Tukey-Kramer test.

Probability $(\mathrm{P})$ value of $<0.05$ was taken as the level of statistical significance.

\section{RESULTS}

Table 1: Number of writhes in group-1 (control, treated with distilled water).

\begin{tabular}{|llll|}
\hline $\begin{array}{l}\text { Mice } \\
\text { No. }\end{array}$ & $\begin{array}{l}\text { Body weight } \\
\text { (grams) }\end{array}$ & $\begin{array}{l}\text { Treatment } \\
\text { Distilled water }\end{array}$ & $\begin{array}{l}\text { No. of } \\
\text { writhers }\end{array}$ \\
\hline 1 & 26 & Distilled water & 44 \\
\hline 2 & 30 & Distilled water & 38 \\
\hline 3 & 25 & Distilled water & 40 \\
\hline 4 & 30 & Distilled water & 36 \\
\hline 5 & 28 & & \\
\hline
\end{tabular}

Table 2: Number of writhes in group-2 (treated with fluoxetine).

\begin{tabular}{|llll|}
\hline $\begin{array}{l}\text { Mice } \\
\text { No. }\end{array}$ & $\begin{array}{l}\text { Body weight } \\
\text { (grams) }\end{array}$ & $\begin{array}{l}\text { Treatment } \\
\text { Fluoxetine }\end{array}$ & $\begin{array}{l}\text { No. of } \\
\text { writhers }\end{array}$ \\
\hline 1 & 25 & Flu \\
\hline 2 & 25 & Fluoxetine & 38 \\
\hline 3 & 30 & Fluoxetine & 33 \\
\hline 4 & 28 & Fluoxetine & 40 \\
\hline 5 & 28 & Fluoxetine & 38 \\
\hline
\end{tabular}

Table 3: Number of writhes in group-3 (treated with pentazocine).

\begin{tabular}{|llll|}
\hline $\begin{array}{l}\text { Mice } \\
\text { No. }\end{array}$ & $\begin{array}{l}\text { Body weight } \\
\text { (grams) }\end{array}$ & Treatment & $\begin{array}{l}\text { No. of } \\
\text { writhers }\end{array}$ \\
\hline 1 & 20 & Pentazocine & 28 \\
\hline 2 & 20 & Pentazocine & 26 \\
\hline 3 & 22 & Pentazocine & 28 \\
\hline 4 & 20 & Pentazocine & 24 \\
\hline 5 & 20 & Pentazocine & 28 \\
\hline
\end{tabular}


Table 4: Summary data for acetic acid induced writhing method.

\begin{tabular}{|lllll|}
\hline Group & $\begin{array}{l}\text { No. of } \\
\text { animals }\end{array}$ & Mean & SD & SEM \\
\hline $\begin{array}{l}\text { A-control } \\
\text { (distilled water) }\end{array}$ & 05 & 39.20 & 3.033 & 1.356 \\
\hline B-Fluoxetine & 05 & 37.00 & 2.646 & 1.183 \\
\hline C-Pentazocine & 05 & 26.80 & 1.789 & 0.800 \\
\hline
\end{tabular}

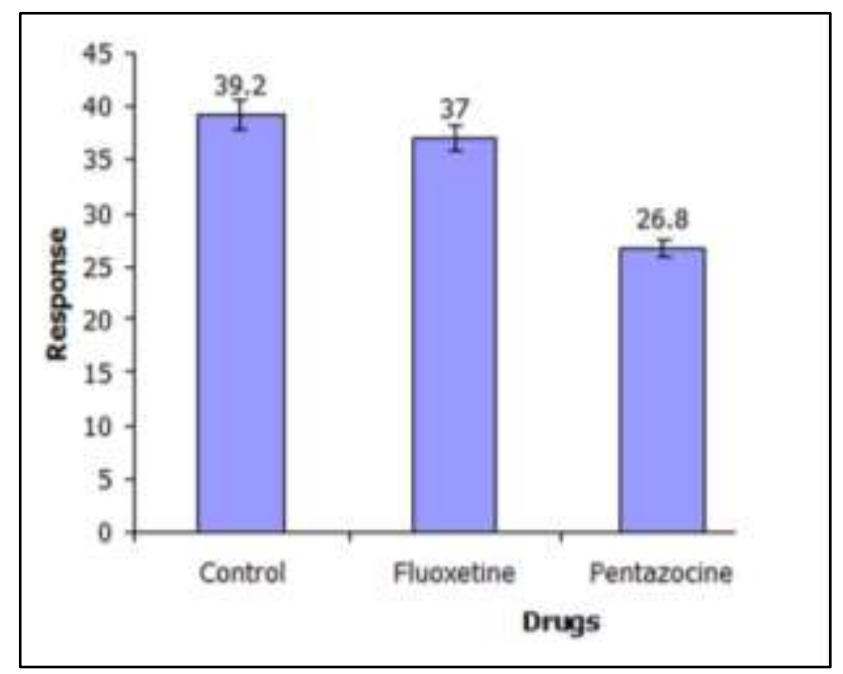

Figure 1: Comparison of response (Mean \pm SEM writhes).

\section{ANOVA results for writhing method}

Tukey-Kramer multiple comparisons test: if the value of $\mathrm{q}$ is greater than 4.046, then the $\mathrm{p}$ value is less than 0.05 .

Table 5: ANOVA results for fluoxetine.

\begin{tabular}{|lll|}
\hline Comparison & q-value & p-value \\
\hline Control versus Fluoxetine & 1.984 & $>0.05$ \\
\hline Control versus Pentazocine & 11.181 & $<0.001$ \\
\hline
\end{tabular}

\section{DISCUSSION}

The study was conducted with three groups of albino rats. $1^{\text {st }}$ group used as control not receiving any drug except distilled water. Drugs, fluoxetine and pentazocine were administered to the other two groups of animals as per protocol. Effect of fluoxetine on nociception was evaluated and was compared with standard analgesic drug pentazocine.

Antinociceptive activity of fluoxetine has been extensively studied in animal nociceptive models with varying results. Hence, the current study was undertaken to study the antinociceptive activity of fluoxetine using Acetic acid induced writhing method in rats.
The present study showed that fluoxetine failed to demonstrate significant analgesic activity ( $p$-value $>0.05$ ) in acetic acid induced writhing method.

Acetic acid induced writhing method evaluates only peripherally acting analgesics like NSAIDs. Failed activity of fluoxetine in acetic acid induced writhing method goes to establish that fluoxetine lacks peripheral analgesic action.

Studies conducted by Kurlekar PN and Bhatt JD, Schreiber $S$ and Pick CG and Nayebi AM et al, Ada Raphaeli et al found analgesic activity of fluoxetine to be significant in various analgesic activity screening models. Whereas Margalit D and Segal M, Max MB et al and Sawynok $\mathbf{J}$ et al using various analgesic screening models using rodent animals found fluoxetine to be lacking significant analgesic activity. ${ }^{6-12}$

The possible mechanisms of action for analgesia proposed are $^{13}$

- Inhibition of GIRK channels

- Inhibition of serotonin (5-hydroxytryptamine; 5-HT) transporters

- Inhibition of the functions of 5-HT2C and 5-HT3 receptors

- Inhibition of nicotinic acetylcholine (Ach) receptors

- Inhibition of voltage-gated $\mathrm{Ca} 2+, \mathrm{Na}+$ and $\mathrm{K}+$ channels and $\mathrm{Cl}$ - channels

- Agonistic action at $\mu$-opioid receptors. ${ }^{14}$

\section{CONCLUSION}

Fluoxetine is an SSRI and one of the most commonly prescribed drug for depression. It is proven to act at multiple sites like serotonin transporter and opioid $\mu$ receptor, both of which may play a role in its analgesic activity.

Because depression is the most common emotional disturbance in patients with chronic pain, an antidepressant with analgesic activity comparable to TCAs and at the same time with better adverse effect profile will be a welcome discovery.

From the present study it is apparent that fluoxetine has significant activity in central analgesic activity model i.e., hotplate method. If proved to be effective from further studies as an effective analgesic, it may be beneficial in patients with chronic pain and associated depression.

Funding: No funding sources

Conflict of interest: None declared

Ethical approval: The study was approved by the Institutional Ethics Committee 


\section{REFERENCES}

1. De Heer EW, Gerrits MMJG, Beekman ATF, Dekker J, van Marwijk HWJ, et al. The association of depression and anxiety with pain: a study from NESDA. PLoS ONE. 2014;9(10):e106907.

2. O'Neil, Christine K, Hanlon JT, Marcum ZA. Adverse effects of analgesics commonly used by older adults with osteoarthritis: focus on non-opioid and opioid analgesics. The American journal of geriatric pharmacotherapy. 2012;10(6):331-42.

3. Fauci AS. Harrison's principles of internal medicine. $17^{\text {th }}$ ed., USA: Mcgraw hill; 2008:81-86.

4. Saarto T, Wiffen PJ. Antidepressants for neuropathic pain. Cochrane Database of Systematic Reviews. 2007;4:CD005454.

5. Seigmund E, Cadmus R, Lu G. Proceedings of the society for experimental biology and medicine. 1957;95;729-31.

6. Kurlekar PN, Bhatt JD. Study of the antinociceptive activity of fluoxetine and its interaction with morphine and naloxone in mice. Indian $\mathrm{J}$ Pharmacol. 2004;36:369-72.

7. Schreiber S, Pick CG. From selective to highly selective SSRIs: a comparison of the antinociceptive properties of fluoxetine, fluvoxamine, citalopram and escitalopram. European Journal of Neuropsychopharmacology. 2006;16(6):464-8.
8. Nayebi AM, Rezazadeh H, Parsa Y. Effect of fluoxetine on tolerance to the analgesic effect of morphine in mice with skin cancer. Pharmacological Reports. 2009;61(3);453-8.

9. Rephaeli A, Gil-Ad I, Aharoni A, Tarasenko I, Tarasenko N, Geffen Y, et al. $\alpha$-amino butyric acid amines of nortriptyline and fluoxetine display improved pain suppressing activity. Journal of Medicinal Chemistry. 2009;52(9):3010-7.

10. Margalit D, Segal M. A pharmacologic study of analgesia produced by stimulation of the nucleus locus coeruleus. Journal of Psychopharmacology. 1979;62;169-73.

11. Max MB, Lynch SA, Muir J, Shoaf SE, Smoller B, Dubner R. Effects of desipramine, amitriptyline, and fluoxetine on pain in diabetic neuropathy. New England Journal of Medicine. 1992;326:1250-6.

12. Sawynok J, Esser MJ, Reid AR. Peripheral antinociceptive actions of desipramine and fluoxetine in an inflammatory and neuropathic pain test in the rat. Pain. 1999;82(2):149-58.

13. Jung AC, Staiger T, Sullivan M. The efficacy of selective serotonin reuptake inhibitors for the management of chronic pain. American college of physicians journal Club. 1998;128(1):3.

14. Kobayashi T, Washiyama K, Ikeda K. Inhibition of G-protein activated inwardly rectifying potassium channels by fluoxetine (Prozac). British Journal of Pharmacology. 2003;138:1119-28.

Cite this article as: Manjunatha $\mathrm{CH}$, Ratnakar JS. A comparative study of antinociceptive effect of fluoxetine with pentazocine in rodent model. Int $\mathbf{J}$ Basic Clin Pharmacol 2016;5:2267-70. 